\title{
Household transmission of SARS-CoV-2 infection in the Paris/ lle-de-France area
}

\author{
Christine Katlama ${ }^{1,2}$ (D) Yasmine Dudoit ${ }^{1}$. Julien Huyard ${ }^{3} \cdot$ Christine Blanc $^{1} \cdot$ Cathia Soulié $^{4} \cdot$ Luminita Schneider $^{1}$. \\ Antoine Faycal ${ }^{1} \cdot$ Ludovic Lenclume $^{1} \cdot$ Naima Hamani $^{1} \cdot$ Naoual Qatib $^{1} \cdot$ Roland Tubiana ${ }^{1} \cdot$ Sophie Seang ${ }^{1}$. \\ Baptiste Sellem ${ }^{1} \cdot$ Dominique Costagliola $^{3} \cdot$ Romain Palich $^{1} \cdot$ Marc-Antoine Valantin $^{1} \cdot$ Lambert Assoumou $^{3}$
}

Received: 6 April 2021 / Accepted: 6 September 2021 / Published online: 8 January 2022

(c) The Author(s), under exclusive licence to Springer-Verlag GmbH Germany, part of Springer Nature 2021

\begin{abstract}
This study aims to evaluate the prevalence of SARS-CoV-2 antibodies in locked-down family households to determine viral dynamics and immunity acquisition. COVID-19 individuals and their households in lockdown under the same roof during early spring 2020 were interviewed and tested using rapid immunochromatographic lateral flow antibodies assays (LFA) between July and September 2020. Outcomes were secondary infection rate (SIR) among contacts, household infection rate, and predictors of transmission. We enrolled 87 households including 87 COVID-19 index cases (female 78.2\%; median age: 47.0 years, IQR: $42.0-51.5$ ) and 255 contacts (males: 52.9\%; median age: 19.0 years, IQR: 11.0-43.5) consisting of their children (42\%) or spouses/partners (28.2\%). A total of 95/255 contacts were SARS-CoV-2 antibody positive leading to a SIR of 37.3\% (95\% confidence interval (CI): 31.3-43.5\%). Viral transmission was observed in 54 households (62\%). SARS-CoV-2 infection was asymptomatic in 33/95 (34.7\%) of SARS-CoV-2-positive contacts. Independent predictors of virus transmission from index to contacts were housing surface area $<60 \mathrm{~m}^{2}(\mathrm{OR}: 5.6$ [1.1; 28.2] and a four-member family compared to five (OR: $3.6[1.2 ; 10.3])$. Households represent a high-risk setting for SARS-CoV-2 transmission through close contact within the family amplified by the number of family members and the housing surface area.
\end{abstract}

Keywords SARS-CoV-2 infection $\cdot$ Household transmission $\cdot$ Healthcare workers $\cdot$ SARS-CoV-2 antibodies

\section{Introduction}

The COVID-19 illness course is highly heterogeneous ranging from asymptomatic, mild or moderate disease to severe disease with a potential for lethal acute respiratory distress

Christine Katlama

christine.katlama@aphp.fr

1 Department of Infectious Diseases, INSERM, Pierre Louis Epidemiology and Public Health Institute (iPLESP), AP-HP, Pitié-Salpêtrière Hospital, Sorbonne Université, 1675013 Paris, France

2 Service des Maladies Infectieuses et Tropicales, Hôpital Pitié-Salpêtrière, AP-HP 47-83 Boulevard de l'hôpital, 75013 Paris, France

3 INSERM, Pierre Louis Epidemiology and Public Health Institute (iPLESP), Sorbonne Université, 75013 Paris, France

4 Department of Virology, INSERM, Pierre Louis Epidemiology and Public Health Institute (iPLESP), AP-HP, Pitié-Salpêtrière Hospital, Sorbonne Université, 75013 Paris, France syndrome [1-3]. As SARS-CoV-2 is spread mostly through close contact with infected people excreting the virus through infected respiratory droplets or saliva, crowded indoor environments and particularly households with sustained close contact represent a particularly high-risk setting [4-6].

Household transmission studies for COVID-19 are key to understanding the dynamics of transmission and the factors associated with secondary transmission [1,7].

Several studies of SARS-CoV-2 household transmission using RT-PCR detection assays have reported a secondary transmission rate ranging from 3.7 to $19 \%$ [7-13]. However, as the virus rapidly disappears from the respiratory tract within days in most infected individuals [14, 15], antibody detection may offer more opportunity to assess the extent of viral spread within households. Serological tests are positive within 5-14 days following infection, with seroconversion rates from 80 to $100 \%$ [15]. Like many countries during the first wave of the pandemic, France was in full lockdown including schools from March 16 to May 11, 2020, to reduce 
human mobility [16]. At that time, facial masks and testing were scarcely available in France for the general population and detection of SARS-CoV-2 by nasal PCR was limited mainly to hospitalized patients and healthcare workers.

We designed the FAMICOV study to assess the rate of transmission of SARS-CoV-2 in households with COVID-19 cases with RT-PCR-confirmed COVID-19 during the first wave of the epidemic, using anti-SARS-CoV-2 antibody detection, and to determine potential risk factors associated with transmission.

\section{Methods}

\section{Study design}

The FAMICOV study (FAMily COVid-19) was designed as a cross-sectional, single-center seroprevalence study to assess transmission of SARS-CoV-2 virus in exposed contacts sharing residence with one adult individual with confirmed COVID-19 defined as presumed index case. The primary outcome was secondary infection transmission rate (SIR) within contacts detected by the presence of SARSCoV-2 antibodies between July and September 2020. Secondary outcomes included the proportion of households with at least one secondary transmission, the risk of transmission from one presumed index to their household contacts tested SARS-CoV-2 antibodies positive, the potential risk factors associated with transmission such as type of COVID-19 symptoms, the nasopharyngeal cycle threshold (Ct) of RTPCR in the index case, and the household living conditions including lodging surface area, bedroom, and meal sharing.

\section{Study population}

Eligible households had to include one individual (presumed index case) with positive nasopharyngeal RT-PCR infection from March 20 to April 20, 2020, living under the same roof as at least 2 members older than 3 years of age. During this first wave COVID-19 period, although national guidelines recommended wearing facial masks, access to masks and tests were limited. All household contacts had to be available for antibody testing between July 3 and September 15, 2020. Index cases were part of the cohort of individuals with COVID-19 followed on an outpatient basis, conducted at Pitié-Salpêtrière University Hospital (Paris, France). Eligible households were contacted by phone or text message between June 25 and July 10 . Index cases and all contact individuals sharing the same residence at the time of index disease who had given their consent to take part in the study were interviewed and tested for SARS-CoV-2 antibodies between early July and mid-September at the Outpatient
Clinic of the Infectious Diseases Department at Pitié-Salpêtrière Hospital.

The study period was limited to ensure that antibody testing would be performed prior to a potential second wave of the epidemic that emerged in France in early October 2020.

Data were collected from index cases and contacts through a standardized questionnaire including demographics, underlying conditions, onset of symptoms, housing conditions, bedroom and meal sharing, and facial mask availability. All index cases had to have a proven COVID19 diagnosis attested by a positive RT-PCR nasopharyngeal swab.

\section{Biological procedures}

The Cobas ${ }^{\circledR}$ SARS-CoV-2 test (Roche), the RealStar ${ }^{\circledR}$ SARS-CoV-2 RT-PCR Kit 1.0 assay, and a real-time RTPCR [17] were used to detect SARS-CoV-2 RNA. Only the Roche Cobas ${ }^{\circledR}$ SARS-CoV-2 assay was used to assess semiquantification of the virus, considering the cycle threshold as a proxy for quantification to estimate viral load. Contact cases were adults or children above 3 years old, sharing the same household as an index case at the time of COVID-19 diagnosis.

Each index case and all contact individuals were tested using the rapid immunochromatographic lateral flow assay (LFA) COVID-PRESTO manufactured by AAZ detecting total SARS-CoV-2 IgG, IgM, or both antibodies targeting the N-protein with a sensitivity of $78.4 \%$ and $92.0 \%$ and a specificity of $100 \%$ and $92 \%$ for IgM and IgG [18].Testing was performed by a research nurse under medical supervision in finger-prick-obtained capillary blood. In the event of a positive result, the index case and adult contacts were offered a confirmation plasma serology test. The presence of IgG antibodies against the nucleocapsid protein was measured and interpreted using commercially available chemiluminescent microparticle immunoassay (CMIA) kits according to the manufacturer's instructions (SARS-CoV-2 IgG, Architect, Abbott).

A positive contact was defined as a contact of an index case with presence of SARS-CoV-2 antibodies. A positive household was defined as a household with at least one contact with SARS-CoV-2 antibodies whereas the absence of any positive contact defined a negative household.

\section{Statistical analysis}

No formal statistical hypothesis was predefined. The study aimed to explore household transmission of COVID-19. It was anticipated that 150 household index cases and 300 to 450 household contacts could be recruited based on the number of individuals diagnosed with PCR COVID-19 in the hospital. With 300 to 450 household contacts, the precision 
of the transmission rate will range from 2.8 to $5.2 \%$ for a transmission rate ranging from 10 to $30 \%$. However, given the rising signs of a second wave, recruitment was stopped on September 16, 2020.

We summarized household environment characteristics, as well as demographic characteristics of index and household contact individuals. The comparisons between groups were tested using Fisher's exact test or Pearson's chi-squared test for categorical variables and the Mann-Whitney $U$ test for continuous variables.

We estimated SIR as the proportion of participating household contacts with secondary infections. The 95\% confidence interval (CI) for binomial distribution was constructed using the exact Clopper-Pearson method. We also estimated the probability of transmission in a household using a two-level (patient-level and household-level) hierarchical logistic regression model with random intercept, taking into account the variability at each level. Characteristics of household environments, index individuals, and household contacts were assessed as potential risk factors. We estimated unadjusted and adjusted odds ratios (OR) and 95\% CI for potential risk factors of secondary infection among household contacts using a two-level hierarchical logistic regression model with random intercept. Variables with a univariable $p$-value below 0.20 were retained for the multivariable analysis.

All $p$-values are reported for two-tailed tests with a significance threshold of 0.05 . The analyses were performed with SAS ${ }^{\circledR}$ version 9.4 for Windows.

\section{Ethics}

Every adult household member provided informed consent to participate. For children less than 18 years, informed consent was obtained from parents/guardians as well as assents from all children aged $\geq 12$ years. This study was conducted in accordance with the Helsinki Declaration. The research was approved by an institutional review board (CPP Sud-Est V, Grenoble, France, \#20-CREP-01) on June 11, 2020.

\section{Results}

\section{Study population}

Out of 189 households with index cases contacted between June 26 and July 10, 2020, 87 households were enrolled between June 27 and September 15. The remaining 102 households either did not have the RT-PCR criteria $(n=46)$, did not respond ( $n=32$ ), or declined to participate because the whole household could not be available for testing during the study period ( $n=24)$ which overlapped with the summer vacation period. The 87 analyzed households included
87 index cases and 255 contacts with a median number of 4.0 persons per household including the index case (IQR: $3.0-4.0)$.

Characteristics of index and contact individuals are shown in Table 1. Residences were in Paris (33.3\%) or the greater Paris area $(66.7 \%)$ and consisted in apartments $(64.4 \%)$ or houses (35.6\%) of a median size of $90 \mathrm{~m}^{2}$ (IQR: 75-120). The median housing density was 4.1 individuals $/ 100 \mathrm{~m}^{2}$. Facial masks were available in $56.3 \%$ of households.

\section{Index cases (Table 1)}

The 87 index individuals were mainly female (78.2\%) with a median age of 47.0 years, most of whom were healthcare workers $(81 \%)$. Eleven (12.6\%) had comorbidities (hypertension $n=10$, overweight $n=3$ ). Out of the $37 / 87$ nasopharyngeal RT-PCR swabs assessed with the COBAS technique, the median CT value was 28.6 (IQR: 21.1-30.6). All index cases except one had symptomatic COVID-19 with mainly respiratory symptoms (72.4\%); ear, nose, and throat (ENT) symptoms (72.4\%); and digestive symptoms (43.7\%). Nine patients (10.3\%) were hospitalized for COVID-19. Overall, $36.8 \%$ of index cases wore facial masks in the presence of contacts, $58 \%(n=50 / 86)$ shared their bedroom mostly with spouses/partners $(n=47 / 50)$ whereas 36 of them $(42 \%)$ had an individual room. Meals were taken separately from other household members for 34/86 (39.5\%) of them.

\section{Household contacts (Table 1)}

The 255 household contacts were males $(52.9 \%)$ and females (47.1\%) of a median age of 19.0 years (IQR: 11.0-43.5), including children from 3 to 10 years $(n=58,22.7 \%)$, $11-17$ years $(n=59 ; 23.1 \%)$, adults aged $18-40$ years $(n=68,26.7 \%)$, or $>40$ years $(n=70 ; 27.5 \%)$. Contact individuals were children (65.1\%) or spouses/partners (28.2\%) of index cases. A majority (82.4\%) of contacts did not wear masks in the presence of others, and shared meals at home $(88.1 \%)$.

\section{Secondary infection rate in contacts (Tables 2 and 3)}

All 255 household contacts were tested either by rapid LFA tests, ELISA, or both assays for 179 (70.2\%), 27 (10.6\%), and 49 (19.2\%) individuals, respectively. Median time from index positive PCR and antibody testing was 121 days (IQR: 107.0-146.5). Positive contacts tended to be older: 20 years (IQR: 11.0-48.0) than negative ones: 18 years (IQR: $11.0-36.2, p=0.098$ ).

Overall, 95 of the 255 contacts had positive SARSCoV-2 antibodies leading to a secondary infection rate (SIR) of $37.3 \%$ (95\% CI: 31.3-43.5\%). Transmission rates were $34.5 \%$ (95\% CI: $22.5-48.1 \%$ ) in the $3-10$-year-old 
Table 1 Characteristics of household index and contact individuals

\begin{tabular}{|c|c|c|c|c|}
\hline & & & $\begin{array}{l}\text { Index } \\
n=87\end{array}$ & $\begin{array}{l}\text { Contacts } \\
n=255\end{array}$ \\
\hline \multirow[t]{6}{*}{ Age, years } & \multirow{6}{*}{$\begin{array}{l}\text { Median (IQR) } \\
n(\%)\end{array}$} & & $47.0(42.0-51.5)$ & $19.0(11.0-43.5)$ \\
\hline & & $3-10$ years & & $58(22.7 \%)$ \\
\hline & & $11-17$ years & & $59(23.1 \%)$ \\
\hline & & $18-40$ years & $19(21.8 \%)$ & $68(26.7 \%)$ \\
\hline & & $41-50$ years & $43(49.4 \%)$ & $39(15.3 \%)$ \\
\hline & & $>50$ years & $25(28.7 \%)$ & $31(12.2 \%)$ \\
\hline \multirow[t]{2}{*}{ Gender } & \multirow[t]{2}{*}{$n(\%)$} & Male & $19(21.8 \%)$ & $135(52.9 \%)$ \\
\hline & & Female & $68(78.2 \%)$ & $120(47.1 \%)$ \\
\hline \multirow[t]{5}{*}{ Symptoms } & \multirow{5}{*}{$\begin{array}{l}\text { Median (IQR) } \\
n(\%)\end{array}$} & & $86 / 87(98.9 \%)$ & $131 / 254(51.6 \%)$ \\
\hline & & Respiratory & $63(72.4 \%)$ & \\
\hline & & Ear, nose, and throat & $63(72.4 \%)$ & \\
\hline & & Digestive & $38(43.7 \%)$ & \\
\hline & & Other & $5(5.7 \%)$ & \\
\hline $\begin{array}{l}\text { Time from symptom onset to } \\
\text { the date of PCR test (days) } \\
N=86\end{array}$ & \multicolumn{2}{|l|}{ Median (IQR) } & $4.0(2.0-7.0)$ & \\
\hline $\begin{array}{l}\text { Time from PCR positive to serological test } \\
\text { (days) }\end{array}$ & \multicolumn{2}{|l|}{ Median (IQR) } & $100.0(79.0-122.0)$ & \\
\hline \multirow{4}{*}{$\begin{array}{l}\text { RT-PCR, Ct value } \\
N=61\end{array}$} & \multirow{4}{*}{$\begin{array}{l}\text { Median (IQR) } \\
n(\%)\end{array}$} & & $28.6(21.1-30.6)$ & \\
\hline & & $<22 \mathrm{Ct}$ & $16(26.2 \%)$ & \\
\hline & & $22-32 \mathrm{Ct}$ & $31(50.8 \%)$ & \\
\hline & & $>32 \mathrm{Ct}$ & $14(23.0 \%)$ & \\
\hline $\begin{array}{l}\text { Normalized RT-PCR, } \\
\mathrm{Ct} \text { values (Ct/days)* } \\
N=58\end{array}$ & Median (IQR) & & $5.5(3.3-9.5)$ & \\
\hline \multirow[t]{5}{*}{ Relationship with index case } & \multirow[t]{5}{*}{$n(\%)$} & Child $3-10$ years & & $58(22.8 \%)$ \\
\hline & & Child $11-17$ years & & $59(23.1 \%)$ \\
\hline & & Child $18-30$ years & & $49(19.2 \%)$ \\
\hline & & Spouses & & $72(28.2 \%)$ \\
\hline & & Other adults & & $17(6.7 \%)$ \\
\hline \multirow{4}{*}{$\begin{array}{l}\text { Housing total surface, } \mathrm{m}^{2} \\
N=87\end{array}$} & \multirow[t]{4}{*}{ Median (IQR) } & & $90.0(75.0-120.0)$ & \\
\hline & & $<60 \mathrm{~m}^{2}$ & $6 / 85(7.1 \%)$ & \\
\hline & & $60-90 \mathrm{~m}^{2}$ & $39 / 85(45.9 \%)$ & \\
\hline & & $>90 \mathrm{~m}^{2}$ & $40 / 85(47.1 \%)$ & \\
\hline \multirow[t]{4}{*}{ Housing surface per subject, $\mathrm{m}^{2}$} & \multirow{4}{*}{$\begin{array}{l}\text { Median (IQR) } \\
n(\%)\end{array}$} & & $22.7(17.5-30.0)$ & \\
\hline & & $\leq 15 \mathrm{~m}^{2}$ & $9(10.4 \%)$ & \\
\hline & & $16-25 \mathrm{~m}^{2}$ & $43(49.4 \%)$ & \\
\hline & & $>25 \mathrm{~m}^{2}$ & $35(40.2 \%)$ & \\
\hline \multirow[t]{5}{*}{ Total family members } & \multirow{5}{*}{$\begin{array}{l}\text { Median (IQR) } \\
n(\%)\end{array}$} & & $4.0(3.0-4.0)$ & \\
\hline & & 3 members & $30(34.5 \%)$ & \\
\hline & & 4 members & $37(42.5 \%)$ & \\
\hline & & 5 members & $16(18.4 \%)$ & \\
\hline & & 6 members & $4(4.6 \%)$ & \\
\hline \multirow[t]{2}{*}{ Mask availability } & & Yes & $49(56.3 \%)$ & \\
\hline & & No & $38(43.7 \%)$ & \\
\hline
\end{tabular}

*The normalized RT-PCR Ct values are the RT-PCR Ct values divided by the time spent between symptoms onset and the date of RT-PCR 
Table 2 Clinical characteristics of household contacts with positive versus negative SARS-CoV-2 antibodies

\begin{tabular}{|c|c|c|c|c|c|}
\hline & & & $\begin{array}{l}\text { Positive serology } \\
\text { household contacts } \\
(N=95)\end{array}$ & $\begin{array}{l}\text { Negative serology } \\
\text { household contacts } \\
(N=160)\end{array}$ & $p$ value \\
\hline \multirow[t]{6}{*}{ Age, years } & \multirow{6}{*}{$\begin{array}{l}\text { Median (IQR) } \\
n(\%)\end{array}$} & & $20.0(11.0-48.0)$ & $18.0(11.0-36.2)$ & 0.098 \\
\hline & & $3-10$ years & $20(21.1 \%)$ & $38(23.8 \%)$ & 0.304 \\
\hline & & $11-17$ years & $21(22.1 \%)$ & $38(23.8 \%)$ & \\
\hline & & $18-40$ years & $21(22.1 \%)$ & $47(29.4 \%)$ & \\
\hline & & $41-50$ years & $17(17.9 \%)$ & $22(13.8 \%)$ & \\
\hline & & $>50$ years & $16(16.8 \%)$ & $15(9.4 \%)$ & \\
\hline \multirow[t]{2}{*}{ Gender } & \multirow[t]{2}{*}{$n(\%)$} & Female & $50(52.6 \%)$ & $70(43.8 \%)$ & 0.195 \\
\hline & & Male & $45(47.4 \%)$ & $90(56.2 \%)$ & \\
\hline \multirow[t]{5}{*}{ Relationship with index case } & \multirow[t]{5}{*}{$n(\%)$} & Child 3-10 years & $20(21.1 \%)$ & $38(23.8 \%)$ & 0.571 \\
\hline & & Child $11-17$ years & $21(22.1 \%)$ & $38(23.8 \%)$ & \\
\hline & & Child $18-30$ years & $15(15.8 \%)$ & $34(21.3 \%)$ & \\
\hline & & Spouse & $31(32.6 \%)$ & $41(25.6 \%)$ & \\
\hline & & Other adults & $8(8.4 \%)$ & $9(5.6 \%)$ & \\
\hline \multirow[t]{4}{*}{ Housing surface, $\mathrm{m}^{2}$} & \multirow{4}{*}{$\begin{array}{l}\text { Median (IQR) } \\
n(\%)\end{array}$} & & $90(73-120)$ & $92(80-115)$ & 0.497 \\
\hline & & $<60 \mathrm{~m}^{2}$ & $10(10.9 \%)$ & $5(3.2 \%)$ & 0.055 \\
\hline & & $60-90 \mathrm{~m}^{2}$ & $41(44.6 \%)$ & $74(46.8 \%)$ & \\
\hline & & $>90 \mathrm{~m}^{2}$ & $41(44.6 \%)$ & $79(50.0 \%)$ & \\
\hline \multirow[t]{4}{*}{ Housing surface per subject, $\mathrm{m}^{2}$} & \multirow{4}{*}{$\begin{array}{l}\text { Median (IQR) } \\
n(\%)\end{array}$} & & $22.5(17.5-30.0)$ & $23.3(17.0-30.0)$ & 0.932 \\
\hline & & $\leq 15 \mathrm{~m}^{2}$ & $17(17.9 \%)$ & $13(8.1 \%)$ & 0.063 \\
\hline & & $16-25 \mathrm{~m}^{2}$ & $47(49.5 \%)$ & $86(53.8 \%)$ & \\
\hline & & $>25 \mathrm{~m}^{2}$ & $31(32.6 \%)$ & $61(38.1 \%)$ & \\
\hline \multirow[t]{4}{*}{ Total family members, } & \multirow{4}{*}{$\begin{array}{l}\text { Median (IQR) } \\
n(\%)\end{array}$} & & $4(4-4)$ & $4(4-5)$ & 0.240 \\
\hline & & 3 members & $20(21.1 \%)$ & $40(25.0 \%)$ & 0.012 \\
\hline & & 4 members & $53(55.8 \%)$ & $58(36.3 \%)$ & \\
\hline & & $\geq 5$ members & $22(23.2 \%)$ & $62(38.7 \%)$ & \\
\hline Wearing mask & $n(\%)$ & & $21(22.1 \%)$ & $24(15.0 \%)$ & 0.175 \\
\hline \multirow[t]{2}{*}{ Sharing meal } & \multirow[t]{2}{*}{$n(\%)$} & & $52(54.7 \%)$ & $93(58.1 \%)$ & 0.604 \\
\hline & & & $62(65.9 \%)$ & $69(43.1 \%)$ & 0.001 \\
\hline \multirow{5}{*}{$\begin{array}{l}\text { Presence of symptoms according to } \\
\text { age, years }\end{array}$} & \multirow[t]{5}{*}{$n(\%)$} & $3-10$ years & $8 / 20(40.0 \%)$ & $18 / 38(47.4 \%)$ & 0.782 \\
\hline & & $11-17$ years & $11 / 21(52.4 \%)$ & $14 / 38(36.8 \%)$ & 0.282 \\
\hline & & $18-40$ years & $13 / 20(65.0 \%)$ & $22 / 47(46.8 \%)$ & 0.194 \\
\hline & & $41-50$ years & $16 / 17(94.1 \%)$ & $11 / 22(50.0 \%)$ & 0.004 \\
\hline & & $>50$ years & $14 / 16(87.5 \%)$ & $4 / 15(26.7 \%)$ & $<0.001$ \\
\hline Cough & $n(\%)$ & & $27(28.4 \%)$ & $30(18.8 \%)$ & 0.087 \\
\hline Fever & $n(\%)$ & & $40(42.1 \%)$ & $28(17.5 \%)$ & $<0.001$ \\
\hline
\end{tabular}

group, $35.6 \%$ (95\% CI: $23.6-49.1 \%$ ) in the 11-17-year-old group, and $30.9 \%$ (95\% CI: $18.3-45.4 \%$ ) in the $18-40$-yearold group. The SIR was $43.1 \%$ (95\% CI: $31.4-55.3 \%)$ in spouses/partners.

At least one secondary SARS-CoV-2 transmission occurred in 54 of the 87 households $(62.1 \%, 95 \% \mathrm{CI}$ : 51.0-72.3\%) (positive households) while 33 households $(37.9 \%, 95 \%$ CI: $27.7-49.0 \%)$ remained free of transmission (negative households). In positive households, $87.0 \%$ of index cases were older than 40 years versus $63.6 \%$ in negative households $(p=0.016)$. Overall, the probability of SARS-CoV-2 transmission from index cases to contacts within a single household was 33.0\% (95\% CI: 23.8-43.9). Infection rate tends to be higher in case of smaller housing surface per individual $(p=0.063)$. Out of the 49 contacts with 2 antibody assays, 45 were positive using both tests and 4 were negative in ELISA.

\section{Symptoms in contact individuals (Table 2)}

Out of the 255 contact individuals, 131 individuals $(51.6 \%)$ reported symptoms at the time of index 
Table 3 Univariable and multivariable analyses of potential risk factors for SARS-CoV-2 infection among household contacts using a two-level hierarchical logistic regression model with random intercept

Total number SIR
Univariable analysis, Uni- Multivariable

odds ratio $[95 \% \mathrm{CI}]$ variable $p$ analysis, odds ratio value
Overall $[95 \% \mathrm{CI}]$

\section{$37.3 \%[31.3 ; 43.5]$}

Factors relative to index case

Age, years

$\begin{array}{lll}18-40 \text { years } & 54 & 27.8 \% \\ 40-50 \text { years } & 133 & 39.9 \% \\ >50 \text { years } & 68 & 39.7 \%\end{array}$

\section{Male}

Female

54

RT-PCR, Ct values

$\begin{array}{lll}<22 \mathrm{Ct} & 47 & 44.7 \% \\ 22-32 \mathrm{Ct} & 90 & 34.4 \% \\ >32 \mathrm{Ct} & 41 & 36.6 \% \\ \text { Median (IQR) } & 58 & 5.5(3.3-9.5)\end{array}$

Normalized RT-PCR, Ct

values $(\mathrm{Ct} /$ days $)$

Factors relative to contacts

Age, years

Gender

$\begin{array}{lll}3-10 \text { years } & 58 & 34.5 \% \\ 11-17 \text { years } & 59 & 35.6 \% \\ 18-40 \text { years } & 68 & 30.9 \% \\ 41-50 \text { years } & 39 & 43.6 \% \\ >50 \text { years } & 31 & 51.6 \%\end{array}$

\section{Male}

Female

Family relationship with index case

$\begin{array}{ll}\text { Child 3-10 years } & 58 \\ \text { Child 11-17 years } & 59 \\ \text { Child 18-30 years } & 49 \\ \text { Spouse } & 72 \\ \text { Other adults } & 17\end{array}$

Factors relative to household environment
Housing surface, $\mathrm{m}^{2}$

\section{Median (IQR)}

$<60 \mathrm{~m}^{2}$

$60-90 \mathrm{~m}^{2}$

$>90 \mathrm{~m}^{2}$

Total family members

\section{3 members}

4 members

$\geq 5$ members

Housing surface per sub-

Median (IQR)

ject, $\mathrm{m}^{2}$

$\leq 15 \mathrm{~m}^{2}$

$16-25 \mathrm{~m}^{2}$

$>25 \mathrm{~m}^{2}$

Wearing mask

\section{$44.4 \%$}

$35.3 \%$

(1)

$33.3 \%$

$41.7 \%$

$34.5 \%$

$35.6 \%$

$30.6 \%$

$43.1 \%$

$47.1 \%$

$90(73-120)$

$66.7 \%$

$35.7 \%$

$34.2 \%$

4 (4-4)

$33.3 \%$

$47.7 \%$

$26.2 \%$

$22.5(17.5-30.0)$

$56.7 \%$

$35.3 \%$

$33.7 \%$

$92 \quad 33.7 \%$

$$
\begin{aligned}
& \text { No } \\
& \text { Yes }
\end{aligned}
$$

0.259

1

$2.7[0.8 ; 9.1]$

$2.6[0.7 ; 10.0]$

2.2 [0.6; 7.9]

$2.6[0.6 ; 10.5]$

0.211

$2.0[0.7 ; 5.7]$

1

0.587

$1.4[0.2 ; 8.0]$

$0.7[0.1 ; 3.2]$

1

$1.0[0.9 ; 1.1]$

0.684

0.278
$1.5[0.6 ; 4.3]$

$1.5[0.5 ; 4.0]$

1

$2.9[0.9 ; 9.1]$

$2.6[0.8 ; 8.0]$

0.314

$1.4[0.7 ; 2.8]$

0.395

$1.8[0.6 ; 5.3]$

$1.6[0.5 ; 4.9]$

1

$2.8[1.0 ; 8.3]$

$1.7\{0.3 ; 8.6]$

$1.00[0.99 ; 1.01] \quad 0.340$

$5.6[1.1 ; 28.2] \quad 0.102$

$1.1[0.4 ; 2.6]$

1

$0.85[0.51 ; 1.40]$

0.513

$1.6[0.5 ; 4.9] \quad 0.047$

$3.6[1.2 ; 10.3]$

1

$1.02[0.98 ; 1.05]$

$3.8[0.9 ; 16.3]$

$1.2[0.5 ; 3.1]$

1

$1.6[0.5 ; 4.5]$

$1.1[0.4 ; 3.1]$

1

$2.6[0.8 ; 8.4]$

$2.2[0.7 ; 6.7]$

$39.0 \%$

$1.2[0.5 ; 3.1]$

1 
Table 3 (continued)

\begin{tabular}{lllll}
\hline & Total number & SIR & $\begin{array}{l}\text { Univariable analysis, Uni- } \\
\text { odds ratio [95\% CI] } \begin{array}{l}\text { Multivariable } \\
\text { variable } p \text { valysis, odds ratio } \\
\text { value } \\
{[95 \% \mathrm{CI}]}\end{array}\end{array}$ \\
\hline Sharing meal & & & 0.595 \\
& No & 110 & $39.1 \%$ & $1.3[0.5 ; 3.0]$ \\
& Yes & 145 & $35.9 \%$ & 1 \\
\hline
\end{tabular}

$S I R$, secondary infection rate

COVID-19. Symptoms were more frequent in positive contacts $(n=62 / 95 ; 65.3 \%)$ than in negative contacts $(69 / 160$, $43.1 \%)(p=0.001)$. Prevalence of symptoms increased in positive contacts from $40 \%$ in $3-10$ years old to $61.9 \%$ in 18-40 years old and $93 \%$ in those over 50 years old. They occurred in $40.0 \%$ of the 3-10 years old, $52.4 \%$ of the 11-17 years old, and $59.7 \%$ in contacts over 18 years. Symptoms occurred in a median period of 3.0 days after those of the index case in all except four positive contacts who reported symptoms a few days prior to those of the index case. Out of the 95 positive contacts, 61 had mild COVID-19, one 61-year-old positive female was hospitalized for 5 days, and $33(34.7 \%)$ were asymptomatic.

\section{SARS-CoV-2 antibodies in presumed index cases}

All index cases were tested for specific antibodies using rapid LFA tests $(n=43)$ or ELISA $(n=80)$, with 36 individuals tested with both tests. The median time from positive RT-PCR to antibody tests was 100 days (IQR: 79.0-122.0). SARS-CoV-2 antibodies were positive in 77 of the 87 index cases $(88.5 \%)$. Ten were antibody-negative using both LFA and plasma ELISA. Among the 36 individuals tested for antibodies using the 2 assays, rapid tests and plasma ELISA, 3 had a positive rapid test while ELISA was negative and two were rapid-antibody-testnegative and positive in ELISA.

\section{Factors associated with transmission (Table 3)}

We did not find any factor associated with the risk of transmission from index cases to contacts among those tested: index age, sex, CT of nasopharyngeal RT-PCR, sharing index bedroom, sharing meals, or wearing masks. In contrast, in multivariate analysis, we found a higher SIR in contacts from households with a surface area less than $60 \mathrm{~m}^{2}$ (SIR 66.7\% with OR: 7.4 (1.4-40.6) compared to $34.2 \%$ in surface areas $>90 \mathrm{~m}^{2}$ and in households of 4 members (OR: 3.6 (1.3-10.9) (SIR: $47.7 \%$ versus $26.2 \%$ in 5-member households.

\section{Discussion}

This study of 87 individuals with proven SARS-CoV-2 infection and their 255 family household contacts suggested a high rate of virus circulation with a $37 \%$ rate of possible virus transmission, in a context of full lockdown. Transmission occurred in $62 \%$ of households with a $31.6 \%$ (95\% CI: 22.1-42.9) probability of transmission from one presumed index case after adjusting for the different size of households. Most initial household studies used direct viral detection in nasopharyngeal tracts with a transmission rate of around $20 \%$ [8, 14, 19]. As direct virus detection through RT-PCR, the gold standard of acute infection, is transient, thus requiring a narrow time window to prospectively capture all positive contacts, antibody testing offers a better reflection of exposure to SARS-CoV-2 [20-22]. Our results align with those of Lewis et al. [23] who reported a transmission rate of $29 \%$ in households in Utah and Wisconsin using either PCR or serology or those from NYC [24] reporting a transmission rate of $38 \%$ in 229 cases using molecular SARS-CoV-2 assays, with more severe index cases, mainly male, with over $30 \%$ comorbidities. In a study from Barcelona on 381 primary cases and 1465 household contacts, a similar population to ours, with primary cases predominantly female and $45 \%$ of child contacts, the seroprevalence of SARS-CoV-2 infection in contacts was $18.1 \%$ [25]. This lower transmission rate compared to our results may be explained by lower sensitivity of the rapid LFA test used as suggested by the difference in seropositivity found in paired samples tested for ELISA (around 80\%) and rapid LFA (around 35\%) at weeks 8-12. In our study, with a lag time of 3 months, only $89 \%$ of the RT-PCR positive index cases were antibody positive confirming that antibodies detected may wane over time [3, 16, 20].

Although the durability of SARS-CoV-2 antibody response is still uncertain given the recent emergence of COVID-19, and may become negative after few weeks particularly in asymptomatic individuals [4], antibodies to the SARS-CoV class of viruses have been generally reported to persist over 1-2 years, declining thereafter [26].

Despite early reports about the low prevalence of COVID-19 in children when tested by PCR [27], like others, 
we found children as susceptible to SARS-CoV-2 as adults in family households [24, 25]. Rates of infection were similar between children and adults whereas spouses had higher rates of infection as already reported $[8,9]$.

Our presumed index case population was mostly healthcare workers with wider access to RT-PCR testing during the first pandemic wave. They lived in a standard family in France with spouses/partners (83\%), children (65\%), and had very few comorbidities (unlike the household transmission family study reported from New York state [24]). Our index cases had mild symptoms which resolved within days, consistent with a median nasopharyngeal RT-PCR value of 28.6 CT. Interestingly, even though the number of RT-PCR with CT determinations was low, there was nonetheless a trend for a lower CT RT-PCR to increase transmission, which concords with the risk of longer viral excretion leading to higher potential for transmission.

Symptoms were reported by two-thirds of positive contacts but also by $40 \%$ of negative contacts. This may simply reflect that retrospective symptom assessment may have flawed, or that during this period, most flu-like minor symptoms were not investigated. However, as clearance of antibodies is time-dependent, we cannot rule out that some of these subjects may have encountered the virus with no antibodies detected using LFA tests. Nonetheless, this would reinforce our finding of a high infection rate within a household.

These results must be considered with respect to several limitations. First, we assumed that positive contacts had been infected through household transmission around the positive PCR index case. As antibody testing was performed within 2-3 months after index infection, we cannot rule out that household contacts were infected later even though most of them presented with COVID19-associated symptoms right after the index case. Second, we considered index cases to be the first adult who tested positive by nasopharyngeal RT-PCR, which may reflect this population of mainly healthcare workers' ease of access to viral diagnosis at symptom onset. Four individuals in the study in fact reported symptoms prior to those of the index cases. Overall, we acknowledge that if our study cannot precisely determine the dynamics of transmission within each household as since contacts may have been infected before, simultaneously or after the presumed index case, we are confident that infection rates within households reflect virus circulation within family members. We cannot exclude a memory bias for symptoms at time of quarantine although this may have been mitigated by our simultaneous interview of the whole family, with the expectation that collective remembering would be more reliable. Nevertheless, this does not modify our conclusion as our main objective was to determine the family's overall exposure to the SARS-CoV-2 virus rather than the transmission dynamics that we could not establish retrospectively. Finally, to make the testing visit easier for the whole family, we used a short questionnaire that did not investigate factors in contacts that could increase the risk of virus acquisition such as smoking or comorbidities. However, given their young age with half the contact population less than 18 years, these factors would have played a minor role.

Overall, in this context of full lockdown, the main risk factor associated with transmission from an index case to their family contacts was, not surprisingly, living in a small apartment with more family members. Transmission to spouses was high as indicated [28]. Close contact is barely avoidable within families and despite being highly recommended, strict quarantine of any person with COVID-19 within a family is difficult to implement in real life $[29,30]$. This reinforces the need, in non-immunized individuals, for potent and safe anti-SARS-CoV-2 drugs which could be given not only to index cases but also to contacts as pre- or post-exposure prophylaxis. Today, none of the antiviral drugs investigated in the early phase of the pandemic [31-33] has shown sufficient efficacy data to be strongly recommended [34]. Molnupiravir (MK-4482/ EIDD-2801), a drug effective in reducing SARS-CoV-2 load in the respiratory tract and suppressing virus spread in animal models $[35,36]$, is currently in development $[37,38]$.

In 2021 with the hope of a worldwide vaccination rollout capable of inducing immunogenicity in over $90 \%$ of SARSCoV-2 non-immune individuals [39-41], a key question remains whether SARS-CoV-2 antibody-positive individuals need to be vaccinated and what could be the appropriate vaccine schedule in individuals with past exposure to SARSCoV-2. Large population-based prospective studies should bring a better understanding of the duration of acquired immune protection.

In conclusion, households represent a high-risk setting for SARS-CoV-2 transmission in a context of close contact and a disease which can be modestly apparent. In a context of pandemics, lockdown measures are insufficient to control household transmission. Generalized vaccination for all, easy access to viral diagnosis tests, strict respects of distancing including quarantine hotels for positive cases, currently largely recommended should to decrease transmission within household. If safe, potent oral antivirals drugs emerged in the future, their use both in treatment of SARS$\mathrm{CoV}$-2-infected individuals and in prophylaxis for contacts could be foreseen to stop close-contact transmission.

Acknowledgements We would like to thank the COVIDOM team, Joseph Coulloch (AAZ Company), and Georges Kreplak for their helpful support; Fiona Mac Brearty for English support; and all household family members including the children who have enthusiastically participated to the FAMICOV study. 
Author contribution Christine Katlama, Marc-Antoine Valantin, Lambert Assoumou: study conception, protocol and manuscript writing.

Yasmine Dudoit: regulatory authorities submission, data acquisition, manuscript writing.

Christine Blanc: CRF conception, data acquisition.

Lambert Assoumou, Julien Huyard, Dominique Costagliola: methodology data management and statistical analysis.

Luminita Schneider, Antoine Faycal, Ludovic Lenclume, Naima Hamani, Naoual Qatib, Roland Tubiana, Sophie Seang, Baptiste Sellem, Romain Palich: data acquisition, manuscript reading.

Funding The study was supported by a not-for-profit organization (CREPATS) for purchase of antibodies assays.

The research protocol was reviewed and approved by an institutional review board (CPP Sud-Est V, Grenoble, France, \#20-CREP-01) on June 11, 2020. According to French law (no. 78-17 of 6 January 1978 on computers, files, and liberties), this study has been registered with the CNIL (French National Agency Regulating Data Protection) and was conducted in accordance with the Helsinki Declaration.

\section{Declarations}

Conflict of interest The authors declare no competing interests.

\section{References}

1. Huang C, Wang Y, Li X, Ren L, Zhao J, Hu Y et al (2020) Clinical features of patients infected with 2019 novel coronavirus in Wuhan, China. Lancet 395(10223):497-506. https://doi.org/10. 1016/S0140-6736(20)30183-5

2. Guan W-J, Ni Z-Y, Hu Y, Liang W-H, Ou C-Q, He J-X et al (2020) Clinical characteristics of coronavirus disease 2019 in China. N Engl J Med NEJMoa2002032. https://doi.org/10.1056/NEJMo a2002032

3. Long Q-X, Tang X-J, Shi Q-L, Li Q, Deng H-J, Yuan J et al (2020) Clinical and immunological assessment of asymptomatic SARSCoV-2 infections. Nat Med 26(8):1200-4. https://doi.org/10.1038/ s41591-020-0965-6

4. Meyerowitz EA, Richterman A, Gandhi RT, Sax PE (2020) Transmission of SARS-CoV-2: a review of viral, host, and environmental factors. Ann Intern Med. https://doi.org/10.7326/M20-5008

5. Li Q, Guan X, Wu P, Wang X, Zhou L, Tong Y et al (2020) Early transmission dynamics in Wuhan, China, of novel coronavirusinfected pneumonia. N Engl J Med 382(13):1199-207. https://doi. org/10.1056/NEJMoa2001316

6. Qian H, Miao T, Liu L, Zheng X, Luo D, Li Y (2020) Indoor transmission of SARS-CoV-2. MedRxiv 2020.04.04.20053058. https://doi.org/10.1101/2020.04.04.20053058

7. Madewell ZJ, Yang Y, Longini IM, Halloran ME, Dean NE (2020) Household transmission of SARS-CoV-2: a systematic review and meta-analysis of secondary attack rate. MedRxiv 2020.07.29.20164590. https://doi.org/10.1101/2020.07.29.20164 590

8. Fung HF, Martinez L, Alarid-Escudero F, Salomon JA, Studdert DM, Andrews JR et al (2020) The household secondary attack rate of SARS-CoV-2: a rapid review. Clin Infect Dis. https://doi.org/ 10.1093/cid/ciaa1558

9. Luo L, Liu D, Liao X, Wu X, Jing Q, Zheng J et al (2020) Contact settings and risk for transmission in 3410 close contacts of patients with COVID-19 in Guangzhou, China : a prospective cohort study. Ann Intern Med 173(11):879-87. https://doi.org/ 10.7326/M20-2671
10. Ng OT, Marimuthu K, Koh V, Pang J, Linn KZ, Sun J et al (2020) SARS-CoV-2 seroprevalence and transmission risk factors among high-risk close contacts: a retrospective cohort study. Lancet Infect Dis. https://doi.org/10.1016/S1473-3099(20)30833-1

11. Bi Q, Wu Y, Mei S, Ye C, Zou X, Zhang Z et al (2020) Epidemiology and transmission of COVID-19 in 391 cases and 1286 of their close contacts in Shenzhen, China: a retrospective cohort study. Lancet Infect Dis. https://doi.org/10.1016/S1473-3099(20) 30287-5

12. Jing Q-L, Liu M-J, Yuan J, Zhang Z-B, Zhang A-R, Dean NE et al (2020) Household secondary attack rate of COVID-19 and associated determinants. MedRxiv. https://doi.org/10.1101/2020. 04.11 .20056010

13. Li W, Zhang B, Lu J, Liu S, Chang Z, Cao P et al (2020) The characteristics of household transmission of COVID-19. Clin Infect Dis. https://doi.org/10.1093/cid/ciaa450

14. He X, Lau EHY, Wu P, Deng X, Wang J, Hao X et al (2020) Temporal dynamics in viral shedding and transmissibility of COVID19. Nat Med 1-4. https://doi.org/10.1038/s41591-020-0869-5

15. To KK-W, Tsang Owen T-Yi, Leung W-S, Tam AR, Wu T-C, Lung DC et al (2020) Temporal profiles of viral load in posterior oropharyngeal saliva samples and serum antibody responses during infection by SARS-CoV-2: an observational cohort study. Lancet Infect Dis 0(0). https://doi.org/10.1016/S1473-3099(20)30196-1

16. Estimating the burden of SARS-CoV-2 in France - PubMed. Available at https://pubmed-ncbi-nlm-nih-gov.proxy.insermbibl io.inist.fr/32404476/. Accessed January 11, 2021, n.d.

17. Corman VM, Landt O, Kaiser M, Molenkamp R, Meijer A, Chu DK et al (2020) Detection of 2019 novel coronavirus (2019nCoV) by real-time RT-PCR. Euro Surveill 25(3). https://doi.org/ 10.2807/1560-7917.ES.2020.25.3.2000045

18. Prazuck T, Colin M, Giachè S, Gubavu C, Seve A, Rzepecki V et al (2020) Evaluation of performance of two SARS-CoV-2 rapid IgM-IgG combined antibody tests on capillary whole blood samples from the fingertip. PLoS One 15(9):e0237694

19. Wilkinson K, Chen X, Shaw S (2020) Secondary attack rate of COVID-19 in household contacts in the Winnipeg Health Region, Canada. Can J Public Health 1-5. https://doi.org/10.17269/ s41997-020-00451-x

20. Guo L, Ren L, Yang S, Xiao M, Chang D, Yang F et al (2020) Profiling early humoral response to diagnose novel coronavirus disease (COVID-19). Clin Infect Dis. https://doi.org/10.1093/cid/ ciaa310

21. Zhao J, Yuan Q, Wang H, Liu W, Liao X, Su Y et al (2020) Antibody responses to SARS-CoV-2 in patients of novel coronavirus disease 2019. Clin Infect Dis. https://doi.org/10.1093/cid/ciaa344

22. Lee Y-L, Liao C-H, Liu P-Y, Cheng C-Y, Chung M-Y, Liu C-E et al (2020) Dynamics of anti-SARS-Cov-2 IgM and IgG antibodies among COVID-19 patients. J Infect. https://doi.org/10.1016/j. jinf.2020.04.019

23. Lewis NM, Chu VT, Ye D, Conners EE, Gharpure R, Laws RL et al (2020) Household transmission of SARS-CoV-2 in the United States. Clin Infect Dis. https://doi.org/10.1093/cid/ciaa1 166

24. Rosenberg ES, Dufort EM, Blog DS, Hall EW, Hoefer D, Backenson BP et al (2020) COVID-19 testing, epidemic features, hospital outcomes, and household prevalence, New York State-March 2020. Clin Infect Dis 71(8):1953-9. https://doi.org/10.1093/cid/ ciaa549

25 Brotons P, Launes C, Buetas E, Fumado V, Henares D, de Sevilla MF et al (2020) Susceptibility to SARS-CoV-2 infection among children and adults: a seroprevalence study of family households in the Barcelona Metropolitan Region. Spain Clin Infect Dis. https://doi.org/10.1093/cid/ciaa1721

26. O Murchu E, Byrne P, Walsh KA, Carty PG, Connolly M, De Gascun $C$ et al (2020) Immune response following infection with 
SARS-CoV-2 and other coronaviruses: a rapid review. Rev Med Virol e2162. https://doi.org/10.1002/rmv.2162

27. Tagarro A, Epalza C, Santos M, Sanz-Santaeufemia FJ, Otheo E, Moraleda C et al (2020) Screening and severity of coronavirus disease 2019 (COVID-19) in children in Madrid, Spain. JAMA Pediatr. https://doi.org/10.1001/jamapediatrics.2020.1346

28. Zhongliang W, Wanli Ma, ZhengXin Wu, Gang ZR (2020) Household transmission of SARS-CoV-2. J Infect. https://doi.org/10. 1016/j.jinf.2020.03.040

29. Chu DK, Akl EA, Duda S, Solo K, Yaacoub S, Schünemann HJ (2020) Physical distancing, face masks, and eye protection to prevent person-to-person transmission of SARS-CoV-2 and COVID-19: a systematic review and meta-analysis. Lancet 395(10242):1973-87. https://doi.org/10.1016/S0140-6736(20) 31142-9

30. Kampf G, Brüggemann Y, Kaba HEJ, Steinmann J, Pfaender S, Scheithauer S et al (2020) Potential sources, modes of transmission and effectiveness of prevention measures against SARSCoV-2. J Hosp Infect 106(4):678-697. https://doi.org/10.1016/j. jhin.2020.09.022

31. Cao B, Wang Y, Wen D, Liu W, Wang J, Fan G et al (200) A trial of lopinavir-ritonavir in adults hospitalized with severe COVID19. N Engl J Med NEJMoa2001282. https://doi.org/10.1056/ NEJMoa2001282

32 Wang Y, Zhang D, Du G, Du R, Zhao J, Jin Y et al (2020) Remdesivir in adults with severe COVID-19: a randomised, double-blind, placebo-controlled, multicentre trial. Lancet 395(10236):1569-78. https://doi.org/10.1016/S0140-6736(20)31022-9

33. Goldman JD, Lye DCB, Hui DS, Marks KM, Bruno R, Montejano $\mathrm{R}$ et al (2020) Remdesivir for 5 or 10 days in patients with severe COVID-19. N Engl J Med 383(19):1827-37. https://doi.org/10. 1056/NEJMoa2015301

34. Coronavirus Disease 2019 (COVID-19) (n.d.) Information for NIH applicants and recipients of NIH funding I grants.nih.gov. Available at https://grants.nih.gov/policy/natural-disasters/coronavirus.htm. Accessed January 28, 2021
35. Cox RM, Wolf JD, Plemper RK (2020) Therapeutic MK-4482/ EIDD-2801 blocks SARS-CoV-2 transmission in ferrets. Res Sq. https://doi.org/10.21203/rs.3.rs-89433/v1

36. Rosenke K, Hansen F, Schwarz B, Feldmann F, Haddock E, Rosenke R et al (2020) Orally delivered MK-4482 inhibits SARSCoV-2 replication in the Syrian hamster model. Res Sq. https:// doi.org/10.21203/rs.3.rs-86289/v1

37. Ridgeback Biotherapeutics LP (2021) A phase IIa randomized, double-blind, placebo-controlled trial to evaluate the safety, tolerability and efficacy of EIDD-2801 to eliminate infectious virus detection in persons with COVID-19. clinicaltrials.gov

38. Ridgeback Biotherapeutics LP (2021) The safety of EIDD-2801 and its effect on viral shedding of SARS-CoV-2. clinicaltrials.gov

39 Anderson EJ, Rouphael NG, Widge AT, Jackson A, Roberts PC, Makhene $M$ et al (2020) Safety and immunogenicity of SARSCoV-2 mRNA-1273 vaccine in older adults. N Engl J Med 383(25):2427-38. https://doi.org/10.1056/NEJMoa2028436

40 Walsh EE, Frenck RW, Falsey AR, Kitchin N, Absalon J, Gurtman A et al (2020) Safety and immunogenicity of two RNA-based COVID-19 vaccine candidates. N Engl J Med 383(25):2439-50. https://doi.org/10.1056/NEJMoa2027906

41. Voysey M, Clemens SAC, Madhi SA, Weckx LY, Folegatti PM, Aley PK et al (2021) Safety and efficacy of the ChAdOx1 nCoV19 vaccine (AZD1222) against SARS-CoV-2: an interim analysis of four randomised controlled trials in Brazil, South Africa, and the UK. Lancet 397(10269):99-111. https://doi.org/10.1016/ S0140-6736(20)32661-1

Publisher's note Springer Nature remains neutral with regard to jurisdictional claims in published maps and institutional affiliations. 